\title{
Pembelajaran Sosial Termediasi dan Aktivisme Media Sosial untuk Pola Hidup Berkelanjutan di Indonesia
}

\section{June Cahyaningtyas ${ }^{1 *}$, Wening Udasmoro², dan Dicky Sofjan ${ }^{3}$}

\author{
${ }^{1}$ Mahasiswa Doktoral, Inter-Religious Studies, Sekolah Pasca-Sarjana, Universitas Gadjah Mada, \\ Yogyakarta, Indonesia. E-mail: june.cahyaningtyas@ugm.ac.id \\ ${ }^{2}$ Sastra Perancis, Fakultas Ilmu Budaya, Universitas Gadjah Mada, Yogyakarta, Indonesia. \\ E-mail: udasmoro@ugm.ac.id \\ 3Inter-Religious Studies Sekolah Pasca-Sarjana, Universitas Gadjah Mada, Yogyakarta, Indonesia \\ E-mail: dickysofjan@ugm.ac.id \\ ${ }^{*}$ Penulis Korespondensi
}

\section{Article Info}

\section{Article History}

Received 3 May 2021

Revised 28 Jul 2021

Accepted 9 Aug 2021

\section{Keywords:}

online community, social media activism, social learning, sustainable living.

\section{Kata kunci:}

aktivisme media sosial, komunitas daring, pembelajaran sosial, pola hidup berkelanjutan.

\begin{abstract}
The notion of social media activism has often been linked with both event and heroic acts in the public with the aim to transform the society. The problem with this framework is its reliance upon performance, while lacking of awareness on the mundane aspects of everyday life, where public issues seep into with its own complexity. To fill this gap, the study uses Social Learning Theory as well as Uses and Gratification Theory to understand to what extent social media supports learning for sustainable living. By way of an ethnographic study on online community, the study found that the women under study have utilized the social media strategically to respond to the health issue and environmental problem, especially after the Covid-19 pandemic, through the discourse practice of sustainable living.
\end{abstract}

\begin{abstract}
Abstrak: Gagasan aktivisme sosial media (social media activism) sering kali dikaitkan dengan tindakan-tindakan yang bersifat event dan heroik. Masalah yang timbul adalah kerangka ini mengandalkan pada tindakan yang bersifat tampilan, dan kurangnya perhatian pada aspekaspek keseharian, dimana isu-isu publik sebenarnya terserap masuk dengan segala kompleksitasnya. Guna mengatasi kesenjangan ini, kajian ini menggunakan teori pembelajaran sosial (Social Learning Theory) dan Uses and Gratification Theory untuk memahami sejauh mana media sosial mendukung pembelajaran pola hidup berkelanjutan. Lewat penelitian etnografis pada komunitas online, kajian ini menemukan bahwa para perempuan dalam penelitian ini menggunakan media sosial secara strategis untuk merespons isu kesehatan dan masalah lingkungan, khususnya setelah terjadinya pandemi Covid-19, melalui wacana dan praktik mengenai pola hidup berkelanjutan.
\end{abstract}




\section{PENDAHULUAN}

Aktivisme media sosial adalah penggunaan teknologi jaringan sosial untuk mengorganisasi dan mengoordinasi tindakan yang mendukung perubahan sosial politik di masyarakat (Brown et al., 2017). Dalam perspektif lintas disiplin, Chon dan Park (2020) mengidentifikasi aktivisme media sosial sebagai fenomena sosial di mana terdapat (i) isu yang diperdebatkan, (ii) tindakan kolektif, (iii) solidaritas atas identitas kolektif, dan (iv) adanya upaya untuk menyelesaikan masalah melalui komunikasi. Tindakan dan solidaritas kolektif itu sendiri oleh Micheletti (2004) dibedakan dalam tindakan kelompok (collectivized collective action) dan tindakan individu yang dilakukan bersama-sama (individualized collective action), atau yang oleh Foster et al (2019) disebut sebagai concensus mobilization.

Dengan sifatnya yang lintas disiplin, konsep aktivisme media sosial kerap memancing perdebatan mengenai hubungan media sosial dengan demokrasi partisipatif: apakah media sosial mendorong partisipasi publik dalam kehidupan demokrasi atau tidak. Perdebatan ini menguatkan debat sebelumnya tentang internet dan demokratisasi di antara kelompok skeptis dan optimis, di mana variabel partisipasi masyarakat sebagai warga negara menjadi jantung perdebatannya (Lim, 2013). Sementara kelompok skeptis menilai partisipasi publik secara daring sebagai sesuatu yang banal karena semata-mata mengandalkan kenyamanan (feeling-good mechanism) sehingga tidak memiliki implikasi sosial politik yang berarti, kelompok optimis menilai pertukaran gagasan, perdebatan politik, ataupun keterlibatan warga negara secara daring mampu mendorong perubahan sosial dan reformasi sistem politik.

Kedua pandangan ini sebenarnya lemah dan berbahaya karena tidak mewakili kenyataan sosial yang kompleks. Hal ini disebabkan kecenderungan untuk membedakan realitas daring dari realitas luring. Padahal dampak sosial dari internet ataupun media sosial harus dipahami sebagai interaksi organik di antara teknologi yang terus berevolusi dengan struktur dan relasi sosial-politikbudaya di masyarakat (Lim, 2012). Permasalahannya, sebagian besar penelitian ini disimpulkan dari literatur gerakan sosial dan politik yang melibatkan massa (eventful). Penelitian jenis ini mengabaikan pertimbangan mengenai pengaruh visibilitas pesan di media terhadap pembelajaran sosial (social learning/SL) yang memotivasi seseorang bertindak secara berkesinambungan, alihalih event. Foster et al (2019) menunjukkan, faktor feeling-good justru menjadi elemen penting yang mampu menarik, melibatkan, dan mengikat parapihak untuk mempromosikan isu yang diperjuangkan dalam aktivisme itu sendiri.

Pertimbangan mengenai SL menjadi relevan karena sejak pandemi telah terjadi peningkatan jumlah pengguna aktif media sosial di Indonesia dari 150 juta (Januari 2019) menjadi 170 juta (Januari 2021), dan diperkirakan akan terus meningkat di masa mendatang (Hootsuite We Are Social, 2021). Media sosial telah menjadi bagian dari kehidupan keseharian di masyarakat sehingga pemahaman seseorang mengenai realitas sosial, termasuk pilihan dan respons tindakannya, tidak bisa dilepaskan dari proses mediasi (Blewitt, 2006). Penelitian Chwialkowska (2019) memperlihatkan bagaimana pengadopsian gaya hidup hijau dipengaruhi oleh komunikasi rekan sebaya 
serta figur berpengaruh pada simpul daring.

Analisis media sosial dan SL menjadi dua hal pokok yang tidak terpisahkan dalam kajian literasi (Deaton, 2015) karena prinsip-prinsip pembelajaran sosial melalui pengamatan, peniruan, dan penguatan, bersifat aplikatif untuk pembelajaran literasi termediasi. Secara umum, Social Learning Theory (SLT) dibangun di atas gagasan mengenai relasi dua arah antara individu sebagai mahkluk sosial dan berakal dengan lingkungannya, serta bagaimana keterhubungan ini mendorong perilaku tertentu (McGregor, 2009). Secara khusus, SLT menekankan dinamika dalam proses mengonstruksi pengetahuan, pilihan tindakan, dan kepribadian seseorang, yang melibatkan pengaruh ekspektasi, kontrol diri, serta bagaimana seorang individu memberi makna atas hidupnya di dunia (Jones, 1989), sehingga, alih-alih menjadi konsumen yang pasif, SL memandang interaksi manusia dengan lingkungannya sebagai bagian dari proses pembelajaran kreatif atas diri dan lingkungannya sehingga bersifat ko-konstruktif.

Gagasan yang dikandung SLT sejalan dengan teori Uses and Gratification (U\&G) yang menekankan peran aktif seseorang sebagai konsumen yang selektif memilih dan menggunakan media (Ruggiero, 2018) untuk memenuhi ekspektasinya (Blumler \& Katz, 1974). Teori ini mengubah fokus perhatian dalam analisis media, dari activity (apa yang dilakukan konsumen media) menjadi activeness (bagaimana kesempatan kebebasan dan otonomi dijalankan seseorang dalam situasi komunikasi massa). Meskipun SLT dan U\&G menekankan unsur agensi dalam teorinya, namun U\&G menolak imitasi dan menganggap dorongan diri pribadi dalam bentuk gratifikasi menjadi faktor determinan dari tindakan terarah, sedangkan SLT membuka diri terhadap aspek peniruan yang bersifat selektif selagi menekankan pentingnya regulasi diri dan refleksi diri dalam proses belajar sehingga tidak semata-mata berorientasi pribadi melainkan juga kolektivis (Bandura, 2001). Melekat dengan SLT adalah gagasan penyediaan (affordance) yang menunjukkan dukungan belajar dalam upaya individu merespons lingkungannya secara ko-konstitutif (Jones, 1989).

Penyediaan adalah istilah yang pertama kali digunakan (Gibson, 1979) untuk menjelaskan bagaimana objek persepsi menyediakan properti tindakan terarah. Di U\&G, konsep ini telah dikembangkan dalam Model MAIN (Rathnayake \& Winter, 2018; Sundar, 2008; Sundar \& Limperos, 2013) yang mengimplikasikan perluasan konsep gratifikasi, yakni tidak lagi bersumber dari individu pengguna media, melainkan dari platform teknologi itu sendiri. Model ini membedakan empat jenis penyediaan, yakni Modality (ragam presentasi isi media yang mengaktifkan fungsi persepsi), Agency (peran individu mengolah isi media, terkait peran gatekeeper dan fitur media sosial yang bersifat user-generatedcontent), Interactivity (fungsi interaksional media yang bersifat dinamis), dan Navigability (aliran tindakan yang dimungkinkan di dalam media).

Konsep penyediaan dalam SLT memberi peluang untuk interaksi yang dinamis antara karakter media terpilih dengan faktor sosiokultural. Liberatore et al (2018) menunjukkan bagaimana karakter egaliter dari media sosial mampu mewadahi lahirnya komunitas berbasis praksis (practice community) dan mendorong berkembangnya citizen science yang hirau dengan isu lokal dan berorientasi pada pemecahan masalah. Pyrko et al (2017) menjelaskan bahwa "thinking together" merupakan mekanisme yang memelihara keberlangsungan SL melalui komunitas 
berbasis praktik di media sosial. Sementara Keir et al (2021), memperlihatkan bagaimana jenis komunitas ini berkembang lewat penggunaan tagar di media sosial. Pyysiäinen (2021) dalam studinya juga menunjukkan bagaimana penyediaan sosiokultural mempengaruhi eksekusi tindakan sehingga agensi tidak berdiri sendiri, melainkan transaksional, yakni berubah bersama berubahnya lingkungan belajar.

Dengan mengaitkan SLT dan U\&G, tulisan ini berupaya menjelaskan aktivisme perempuan di media sosial dalam mempromosikan pola hidup berkelanjutan (sustainable living) sebagai respons terhadap isu kesehatan dan lingkungan hidup, sebelum dan sesudah pandemi terjadi. Sustainable living adalah sebuah konsep payung (umbrella concept) yang menaungi seperangkat isu dan tindakan keseharian, baik di tingkat individual maupun kolektif, di daerah perkotaan di berbagai negara di dunia, seperti promosi gerakan daur ulang sampah kota (di New Delhi, Pune, dan Bogota) dan kebun komunitas (di Swedia dan Hong Kong). Di Indonesia, meskipun secara empiris representasi perempuan dalam ragam kegiatan ini cukup tinggi, tapi belum ada kajian yang mencoba mengaitkannya dengan pembelajaran sosial termediasi dan kontribusinya bagi sustainabilitas. Dengan bantuan konsep turunan seperti penyediaan, studi ini mencoba mengisi kesenjangan kajian mengenai media sosial untuk pembelajaran sosial pola hidup berkelanjutan di masyarakat.

\section{METODE}

Untuk mengetahui pengaruh media sosial terhadap pembelajaran sosial di masyarakat mengenai pola hidup berkelanjutan dalam kehidupan seharihari, studi ini menggunakan pendekatan kualitatif dengan metode etnografi. Namun, alih-alih mengikuti pembedaan metode etnografi ke dalam jenis luring dan daring, penelitian ini membenarkan pandangan Markham (2017) bahwa penggunaan internet dalam kehidupan sosial merupakan fakta yang tidak dapat diabaikan. Dengan etnografi, upaya memahami budaya pada sebuah kelompok dilakukan dengan menyelami pengalaman intersubjektif dari individu-individu di dalamnya melalui interaksi dinamis peneliti secara etic dan emic (vom Lehn et al., 2015). Untuk mencapai tujuan ini, etnografi klasik menuntut adanya pengamatan dan keterlibatan aktif peneliti dengan durasi yang cukup lama (Hammersley, 2006). Seluruh proses penelitian ini dilakukan melalui interaksi, secara luring maupun daring, dengan komunitas yang relevan sepanjang bulan Februari 2019 hingga Februari 2021, atau satu tahun sebelum dan sesudah pandemi Covid-19 terjadi. Di samping itu, pengumpulan data juga dilakukan melalui interview dengan jenis pertanyaan deskriptif dan pembanding untuk klarifikasi (Sorrell \& Redmond, 1995).

Terkait penggunaan media sosial untuk SL pada kajian ini, observasi partisipan dilakukan pada komunitas daring, yang didefinisikan sebagai "agregasi sosial yang muncul dari Internet ketika sejumlah orang melakukan diskusi publik secara intens, dengan melibatkan perasaan, hingga membentuk jaringan hubungan interpersonal di ruang maya" (Rheingold, 2000, hal.5). Dengan memperhatikan batasan ini, pengamatan dilakukan pada Instagram yang, bila dibandingkan situs media sosial lainnya, memfasilitasi penyebarluasan gagasan pola hidup berkelanjutan melalui gambar dan teks bertagar yang relevan. Penggunaan tagar merupakan salah satu ekspresi dari karakter media sosial yang bersifat polifonik dan heterogen (Winter \& Lavis, 2020). Penggunaan tagar di media sosial dapat dilihat sebagai representasi debat di 
ruang publik karena memberi kesempatan untuk siapa pun terlibat di dalamnya (Enli \& Simonsen, 2018). Tagar juga memiliki potensi intertekstual sebagai tindakan politik ("hashtag activism") maupun proses literasi, karena dapat mengaitkan sejumlah besar pandangan dan tindakan yang beragam dalam satu gagasan kunci, sehingga menjadikannya ruang diskursif yang cukup efektif (Bonilla \& Rosa, 2015; Yang, 2016), sebagai dasar tindakan politik dan SL.

Penerapan metode etnografi dalam studi ini diarahkan untuk mencapai pengalaman yang mirip dengan komunitas amatan melalui "thick participation" (Samudra, 2008), yakni dengan sejauh mungkin melibatkan diri dalam praktik yang sama dengan informan, dan "immersive cohabitation" (Bluteau, 2021), yakni merepresentasikan diri secara aktif dalam media sosial, agar dapat berinteraksi dan memahami proses pembelajaran yang mereka alami. Di samping itu, peneliti juga melakukan kunjungan dan wawancara langsung ke beberapa komunitas di Yogyakarta, Malang, Bandung, dan Denpasar. Dari sejumlah wawancara yang telah dilakukan, tulisan ini mengangkat tujuh orang perempuan sebagai informan kunci dengan memperhatikan aktivitasnya di media sosial dan membandingkannya dengan aktivitas rill yang dijalankan. Analisis data dilakukan secara deskripsi naratif yang diarahkan untuk mencari tema, pola, atau kebiasaan (Moser \& Korstjens, 2018) yang dialami oleh para informan hingga mencapai gambaran yang cukup mendalam mengenai aktivitas, nilai, dan praktik pembelajaran sosial yang berkembang dalam komunitas.

\section{HASIL DAN PEMBAHASAN}

Hasil immersive cohabitation mengungkap tiga ranah diskusi utama terkait pembahasan pola hidup berkelanjutan dalam percakapan daring, yakni \#zerowaste, \#plasticfree, dan \#growyourownfood di mana dua tagar pertama erat berkaitan.

Tabel 1. Hasil immersive cohabitation

\begin{tabular}{|c|c|c|c|}
\hline $\begin{array}{l}\text { Ranah } \\
\text { diskusi }\end{array}$ & Tagar utama & Relasi terkait & Isi diskusi \\
\hline $\begin{array}{l}\text { Sampah } \\
\text { umum }\end{array}$ & $\begin{array}{l}\text { \#zerowaste \#bebassampah } \\
\text { \#lesswaste \#minimsampah }\end{array}$ & $\begin{array}{l}\text { \#foodloss \#composting } \\
\text { \#organiccomposting } \\
\text { \#mindfulconsumption } \\
\text { \#fastfashion \# ecoenzyme } \\
\text { \#bandungbebassampah }\end{array}$ & $\begin{array}{l}\text { Polusi, sampah rumah } \\
\text { tangga, konsumerisme, } \\
3 \mathrm{R} \text { (reduce-reuse- } \\
\text { recycle), bank sampah }\end{array}$ \\
\hline $\begin{array}{l}\text { Sampah } \\
\text { plastik }\end{array}$ & $\begin{array}{l}\text { \#plasticfree } \\
\text { \#bebassampahplastik }\end{array}$ & $\begin{array}{l}\text { \#zerowaste \#bebasampah } \\
\text { \#lesswaste \#minimsampah } \\
\text { \#worldplasticfree }\end{array}$ & $\begin{array}{l}\text { Kerusakan di laut, polusi } \\
\text { tanah, kebijakan kantung } \\
\text { plastik berbayar }\end{array}$ \\
\hline & & $\begin{array}{l}\text { \#microplastic \# ecobrick } \\
\text { \#plasticfreeocean } \\
\text { \#lautbebassampahplastik }\end{array}$ & \\
\hline Pangan & $\begin{array}{l}\text { \#growyourownfood } \\
\text { \#tanamsendirimakananmu }\end{array}$ & $\begin{array}{l}\text { \#foodsecurity \# ediblegarden } \\
\text { \#kebunpangan } \\
\text { \#berkebundirumah } \\
\text { \#gardeningathome } \\
\text { \#fromgardentotable } \\
\text { \#darikebunkemejamakan }\end{array}$ & $\begin{array}{l}\text { Ketahanan pangan, } \\
\text { kebun organik, kebun } \\
\text { permakultur }\end{array}$ \\
\hline
\end{tabular}


(1) \#zerowaste

Tagar ini memperlihatkan problem sampah di Indonesia, khususnya sampah rumah tangga yang menjadi penyumbang sampah tertinggi. Pencanangan visi nihil sampah 2020 tampak masih jauh dari jangkauan akibat kurang efektifnya fungsi bank sampah, ditambah tingginya ketergantungan masyarakat pada pengelolaan sampah kolektif dan tempat pembuangan sampah akhir (TPA) konvensional. Di Indonesia, pengelolaan sampah rumah tangga dilakukan secara informal, sebagian difasilitasi dan dikoordinasi Dinas Kebersihan dan Lingkungan Hidup (DKLH) di tingkat kabupaten/kota.

Tagar ini juga menunjukkan pengelolaan sampah secara mandiri dan dampak yang timbul bila sampah organik dan non-organik bercampur. Sebagian besar sampah dapur di Indonesia (sekitar 60\%) bersifat organik, sehingga dapat dikelola di tingkat rumah tangga maupun komunal menjadi kompos yang berdaya guna. Cara ini dianggap perlu untuk menghindari ancaman kesehatan dan nyawa manusia, akibat bercampurnya sampah di TPA yang menyebabkan kebakaran maupun longsor, seperti pernah terjadi di Malang, Bandung, dan Tangerang.

Tagar \#zerowaste juga membahas masalah sampah di luar sampah organik, seperti sampah kemasan dan fast fashion. Fast fashion sendiri merupakan suatu praktik diskursif yang otonom mengenai desain produksi dan pemasaran pakaian siap pakai yang merugikan lingkungan karena kecepatan dan volume produksinya yang tinggi. Wacana yang berkembang dalam \#fastfashion meliputi penggunaan bahan baku sintetis berkualitas buruk sehingga apabila dibuang akan sulit terurai hingga penggunaan tenaga kerja murah dalam proses produksinya.

Mencermati luasnya cakupan isu, diskusi \#zerowaste tidak hanya fokus pada kondisi sampah itu sendiri, melainkan juga pentingnya menyikapi masalah sampah, termasuk mengevaluasi nilai guna sampah yang dapat diterapkan dalam perilaku keseharian melalui tindakan pemakaian ulang (reuse) dan daur ulang (recycle). Hal ini terlihat dari kempanye pencegahan sampah melalui konsumsi yang berkesadaran (mindful consumption), memilah sampah dari rumah, hingga meminimalkan sampah yang keluar dari rumah melalui daur ulang sampah. Dalam hal sampah organik, misalnya, reuse dapat dilakukan melalui kegiatan mengompos, sementara recycle dapat dilakukan melalui kegiatan DIY (do-it-yourself).

Melihat luasnya rentang kegiatan yang dapat dilakukan untuk mengurangi sampah, beberapa individu dan komunitas menyelenggarakan kelas atau workshop daring dengan menggunakan platform Whatsapp ataupun telegram. Para peserta kelas ini umumnya perempuan, sementara narasumber untuk kelas ini adalah mereka yang memiliki pengaruh yang tinggi di media sosial terkait pengalaman dan praktik pengelolaan sampah yang telah dijalani dan dibagikan dalam bentuk cerita di Instagram. 
Tabel 2. Wawancara narasumber dan peserta di Pelatihan Kompos di Kelas Whatsapp

\begin{tabular}{|c|c|c|}
\hline Pertanyaan & Mega (35 tahun) & Desi (40 tahun) \\
\hline $\begin{array}{l}\text { Apakah kelas daring cukup } \\
\text { efektif untuk menyampaikan } \\
\text { pembelajaran tentang kompos? }\end{array}$ & $\begin{array}{l}\text { Mungkin tidak lebih efektif. } \\
\text { Tapi, [apakah kelas itu] luring } \\
\text { ataupun daring, jika tidak } \\
\text { dicoba, tidak akan pernah } \\
\text { [tahu] ada hasilnya. Saya } \\
\text { sendiri tidak pernah } \\
\text { menyangka akan ada banyak } \\
\text { orang yang tertarik } \\
\text { mengompos. Tapi ketika saya } \\
\text { berbagi cerita di media sosial } \\
\text { pengalaman saya mengompos } \\
\text { di rumah, ternyata banyak } \\
\text { orang yang bertanya-tanya, } \\
\text { ingin tahu. Sebenarnya, jika } \\
\text { kita mau memandang ini } \\
\text { sebagai proses, maka rasa ingin } \\
\text { tahu itu sendiri sudah satu } \\
\text { langkah kemajuan yang perlu } \\
\text { diapresiasi. }\end{array}$ & $\begin{array}{l}\text { Cukup efektif. Karena di situ } \\
\text { peserta masih boleh bertanya } \\
\text { kepada nara sumber, meskipun } \\
\text { kelasnya sudah berakhir. }\end{array}$ \\
\hline
\end{tabular}

Sumber: penelitian lapangan, November 2020 dan Juli 2020.

(2) \#plasticfree

Tagar ini fokus pada permasalahan sampah plastik di Indonesia akibat ketergantungan yang tinggi pada plastik sekali pakai dan cara yang dapat dilakukan untuk mengurangi ketergantungan tersebut. Isu yang dibahas menyinggung masalah etika, yakni dampak pencemaran sampah plastik pada tanah, air, dan udara, serta hak para pemulung. Praktik keseharian yang selama ini dianggap lumrah dan wajar di masyarakat, seperti membakar, membuang, dan menggabung sampah plastik dengan jenis sampah lainnya (sampah organik, sampah kaca, dan sampah elektronik), juga dikritisi dalam diskusi ini. Diskusi bahkan menyentuh isu hak hidup binatang dan peran manusia sebagai umat beragama sebagai penjaga kelestarian alam.

Kondisi sampah plastik di Indonesia termasuk yang terburuk di dunia. Namun, tagar ini baru mendapat momentum setelah ramainya pemberitaan binatang laut yang menderita dan mati akibat sampah plastik di lautan. Dalam waktu yang kurang lebih bersamaan, beredar video dokumenter di YouTube mengenai penyelam asal Inggris yang berenang di antara sampah plastik di Selat Bali di tahun 2019. Sebagai langkah antisipasi atas dampak sosial ekonomi pariwisata akibat beredarnya video ini, pemerintah Bali di tahun yang sama segera mencanangkan gerakan Bali Bebas Plastik.

Tagar ini juga dipenuhi promosi katalog produk dari sejumlah start up yang mengembangkan kemasan ramah lingkungan dari kulit singkong atau bahan organik lainnya. Namun terdapat perdebatan apakah klaim ini dapat dipertanggungjawabkan atau malah bersifat greenwashing. 
Tabel 3. Wawancara pelaku minim sampah plastik

\begin{tabular}{|c|c|c|}
\hline Pertanyaan & Hana (33 tahun) & Meti (31 tahun) \\
\hline $\begin{array}{l}\text { Bagaimana awal } \\
\text { ketertarikan pada } \\
\text { masalah sampah } \\
\text { plastik? }\end{array}$ & $\begin{array}{l}\text { Awalnya [saya] melihat teman yang } \\
\text { terlebih dulu berupaya mengurangi } \\
\text { plastik. Di media sosial, teman saya } \\
\text { ini suka berbagi pengalamannya } \\
\text { mencegah pemakaian plastik } \\
\text { kemasan. Karena tertarik, saya } \\
\text { mencari tahu lebih banyak lewat } \\
\text { akun media sosial lainnya yang } \\
\text { memang sudah dikenal ramai } \\
\text { mengampanyekan masalah ini. Dari } \\
\text { situ, saya [pun] mulai terbuka } \\
\text { dengan isu plastik itu seperti apa di } \\
\text { Indonesia, dampaknya } \\
\text { [bagaimana], sampai upaya [apa] } \\
\text { yang bisa saya lakukan [untuk } \\
\text { membantu mengatasinya]. }\end{array}$ & $\begin{array}{l}\text { Waktu kuliah dulu saya pernah ikut } \\
\text { kegiatan bersih-bersih sampah di } \\
\text { pantai... sampah plastik di mana- } \\
\text { mana. Ketika saya akhirnya } \\
\text { memutuskan untuk wiraswasta } \\
\text { membuka catering, saya merasa } \\
\text { bersalah karena punya } \\
\text { ketergantungan yang cukup tinggi } \\
\text { pada plastik. Karena bingung [harus } \\
\text { bagaimana], saya lalu memutuskan } \\
\text { untuk ikut pelatihan yang diadakan } \\
\text { oleh seseorang yang sudah sejak lama } \\
\text { saya ikuti media sosial [terkait } \\
\text { perjalanannya mengurangi sampah } \\
\text { dan plastik]. Alhamdulillah, dari situ } \\
\text { saya pelan-pelan mengurangi plastik. } \\
\text { Saya belum bisa benar-benar } \\
\text { melepaskan diri dari plastik, tapi saya } \\
\text { berusaha mencari material pengganti } \\
\text { plastik di makanan yang kami } \\
\text { sediakan. }\end{array}$ \\
\hline $\begin{array}{l}\text { Apa yang dilakukan } \\
\text { untuk terus } \\
\text { menjaga komitmen } \\
\text { dengan praktik } \\
\text { pengurangan } \\
\text { plastik yang sudah } \\
\text { dijalani sejauh ini? }\end{array}$ & $\begin{array}{l}\text { Berbagi cerita di media sosial, } \\
\text { karena saya kok merasa lebih } \\
\text { mudah ya mendapatkan dukungan } \\
\text { dari mereka yang sama-sama } \\
\text { berusaha mengurangi plastik di } \\
\text { media sosial. Di lingkaran } \\
\text { pertemanan riil, [saya] malah } \\
\text { [merasa] agak susah mendapatkan } \\
\text { dukungan seperti itu. }\end{array}$ & $\begin{array}{l}\text { Pelatihan yang saya ikuti dulu punya } \\
\text { grup alumni. Di sana kami saling } \\
\text { mengingatkan dan menguatkan satu } \\
\text { sama lain. Saya juga sering mendapat } \\
\text { dukungan dari lingkaran pertemanan } \\
\text { di media sosial setiap kali saya } \\
\text { bercerita tentang suka duka saya } \\
\text { menjalani usaha sambil berupaya } \\
\text { mengurangi ketergantungan pada } \\
\text { plastik sekali pakai. }\end{array}$ \\
\hline
\end{tabular}

Sumber: penelitian lapangan, September 2020 dan Februari 2020.

\section{(3) \# growyourownfood}

Mendiskusikan akses pada sumber pangan sehat, tagar ini sangat mengemuka pasca pandemi Covid-19. Tagar ini mengedukasi publik mengenai penanaman, mulai dari persiapan tanam, perawatan, perlakuan terhadap penyakit dan hama tanaman, hingga pengolahan hasil panen. Meskipun kebanyakan dari mereka yang menggerakkan diskusi ini bekerja pada kebun kecil, mereka berbagi cara mengoptimalkan hasil kebunnya melalui beragam teknik dan media penanaman, mulai dari vertikultur, akuakultur, hingga hidroponik. Perdebatan tentang apakah penanaman dengan cara hidroponik termasuk kategori organik atau non- organik juga terungkap pada diskusi bertagar ini.

Sejak pandami Covid-19, dua metode berkebun yang ramai didiskusikan dalam tagar ini adalah permaculture dan organic farming. Kedua pendekatan ini mengedukasi masyarakat tentang fungsi kritis tanah dalam produksi pangan yang berkelanjutan dan penguraian sampah organik rumah tangga. Pembelajaran permaculture yang mahal (Rp 5.000.000,00 - Rp 15.000.000,00) dan hanya bisa diakses secara terbatas menjadi murah dan mudah melalui media sosial. Sebelum pandemi, sebuah organisasi permaculture di Bandung yang dipimpin seorang perempuan menginisiasi kelas 
daring permakultur secara gratis, di mana materi disajikan melalui Instagram sementara asistensi penugasan dan tanya jawab dilakukan melalui Whatsapp. Partisipan di kelas itu membagikan proses belajar dan penugasannya melalui akun Instagramnya masing-masing. Setelah pandemi terjadi, organisasi yang sama mengisi kelas berbayar (dengan biaya $\mathrm{Rp}$ 25.000,00 untuk setiap pertemuan) melalui grup whatsapp untuk tema pembelajaran yang spesifik, seperti olah tanah, penyemaian dan perawatan tanaman, hama dan penyakit tanaman, serta pasca panen. Dengan biaya Rp 25.000,00 untuk setiap kelasnya, peserta dapat memilih dan menyesuaikan sendiri tema apa yang ingin dipelajarinya dengan biaya yang cukup terjangkau.

Tabel 4. Wawancara Perempuan Pekebun

\begin{tabular}{ll}
\hline \multicolumn{1}{c}{ Pertanyaan } & \multicolumn{1}{c}{ Sarah (41 tahun) } \\
\hline Sejak kapan Mba & Saya mulai berkebun di tahun 2015. \\
mulai berkebun, & Awalnya ingin sehat dengan cara yang \\
dari mana belajar & mudah lewat [konsumsi] smoothies, tapi \\
berkebun, dan apa & ternyata tidak murah. Sejak itu ingin \\
yang memotivasi & sekali bisa menanam sendiri [tanaman \\
berkebun? & pangan] di rumah. Sebelum benar-benar \\
& memutuskan untuk berkebun juga saya \\
& sudah mencoba membuat kompos di \\
& rumah, tapi komposnya belum berani \\
& dipakai untuk menanam. Baru setelah \\
& belajar di Indonesia Berkebun, saya \\
& memberanikan diri praktik menanam \\
& dengan kompos yang saya buat. \\
& Alhamdulillah, sampai sekarang jalan \\
& terus. Motivasi utama tentu karena ingin \\
& sehat.
\end{tabular}

Pelajaran penting apa yang didapat setelah berkebun dan bagaimana itu mempengaruhi cara pandang Mba terhadap lingkungan?
Sampai sekarang, sudah banyak metode yang saya coba untuk berkebun dan selalu saja ada hal baru yang menarik untuk dipelajari. Tiga tahun terakhir ini saya belajar tentang permaculture dan dari situ saya baru sadar bahwa banyak hal dalam kehidupan itu saling berkaitan. Sebenarnya di sekolah kita juga sudah belajar itu ya, tapi bedanya kita belajar dengan menghafal, sementara ini dari praktik di lapangan. Itulah sebabnya di permaculture kami diajari untuk menjaga tiga nilai dasar dalam inter-relasi ini [earth care, people care, dan fair share]

Sumber: penelitian lapangan, September 2020 dan Februari 2020.

ANALISIS

Berdasarkan thick participation, diketahui bahwa keenam informan memiliki titik berangkat yang berbeda dalam keterlibatannya mewacanakan dan mempraktikkan pola hidup berkelanjutan. Ada yang terpapar dengan isu ini karena ketidaksengajaan (diajak teman mengikuti

\begin{abstract}
Saya mulai serius dengan hobi berkebun setelah seorang teman mengajak saya untuk mengikuti tantangan 30 hari berkebun \#dirumahaja yang diadakan Indonesia Berkebun. Dari situ saya mencoba mengikuti akun Instagram pekebun yang berpengalaman. Meski ketertarikan [saya] untuk berkebun sudah ada sejak sebelum pandemi, kelas berbayar daring yang diadakan saat itu masih tergolong mahal. Namun sejak pandemi, banyak diskusi interaktif tentang berkebun yang tidak berbayar, sehingga saya sangat terbantu. Motivasi untuk berkebun sebenarnya datang dari Nenek yang bertangan dingin... apa saja yang ditanamnya selalu jadi. Saya ingin bisa menanam seperti Nenek saya dulu.
\end{abstract}

Evi (27 tahun)

Banyak sebenarnya, tapi yang paling penting saya pikir... menjaga sesuai takaran, tidak kurang dan tidak berlebihan. Di agama juga sebenarnya itu diajarkan, tapi entah kenapa sering sekali hal itu dilupakan. [Pelajaran] ini melengkapi pelajaran sebelumnya yang saya dapat dari kegiatan mengompos, sebenarnya. Dari mengompos, saya belajar bahwa manusia tidak hidup sendirian. Ada jutaan mikro organisme yang membantu manusia bisa terus bertahan [hidup] hingga sekarang. 
kegiatan bersih pantai; diajak teman mengikuti sayembara yang diadakan komunitas berkebun), namun ada juga yang melihat contoh nyata (teman berusaha mengurangi pemakaian plastik).
Persamaannya, mereka menggunakan Instagram untuk mencari informasi lebih lanjut terkait contoh tindakan yang dapat dilihat dan ditiru.

Grafik 1. Proses pembelajaran sosial mengenai pola hidup berkelanjutan melalui Instagram
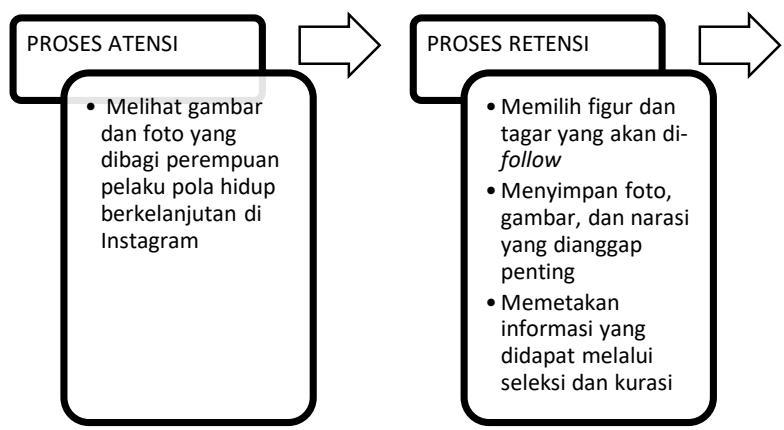

Grafik 1 merupakan konkretisasi dari ilustrasi yang dikembangkan Bandura (2001) terkait proses pembelajaran sosial. Dari Grafik 1 diketahui bahwa proses SL termediasi untuk pola hidup berkelanjutan diawali dengan visual persepsi dan diikuti konstruksi kognitif melalui seleksi dan kurasi informasi. Pembelajaran di tahap ini tak lepas dari penyediaan teknologi Instagram di tahap instrumental, yakni pada aspek Modality dan Navigability (Sundar, 2008; Sundar \& Limperos, 2013).

Proses terpenting terjadi pada tahap ketiga melalui reproduksi tindakan sehingga membentuk pengalaman SL yang utuh, yang membangkitkan penyediaan Agency (Sundar, 2008; Sundar \& Limperos, 2013). Selain melalui praktik pengetahuan terseleksi, reproduksi

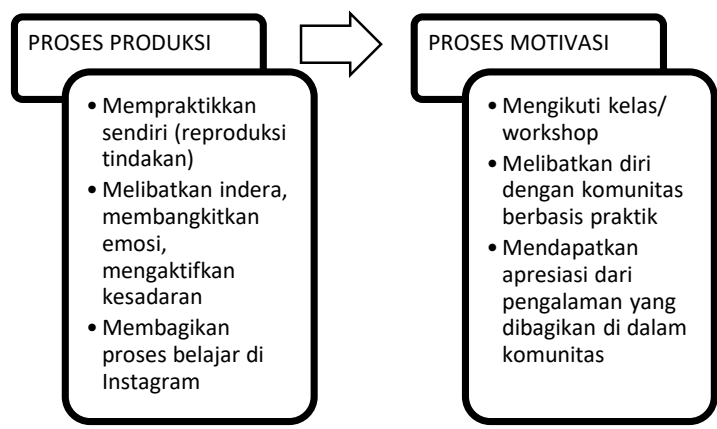

tindakan juga berlangsung lewat pendokumentasian praktik tersebut agar dapat dibagikan kepada lingkaran pertemanan di media sosial. Di Instagram, dokumentasi terjadi melalui kegiatan berbagi cerita dalam bentuk unggahan foto, tulisan, dan video. Selanjutnya, penyediaan Interactivity memungkinkan mereka memperoleh umpan balik positif dari lingkungan pertemanannya. Penguatan positif yang mereka dapatkan menghasilkan feeling good, yang mendorong mereka untuk mengulangi proses yang sama. Selain mendukung siklus belajar, faktor feeling good mengikat mereka dalam aktivitas mempromosikan pola hidup berkelanjutan. Temuan ini, dengan demikian, mengonfirmasi temuan Foster et al (2019) sebelumnya.

Tabel 5. Penyediaan teknologi (technological affordance) Instagram dalam pembelajaran sosial mengenai pola hidup berkelanjutan berdasarkan Model MAIN

\begin{tabular}{cccc}
\hline Modality & Agency & Interactivity & Navigability \\
\hline Photo-sharing & Tagar untuk komunitas & Interaksi & Browsing \\
Video-sharing & Narasi - story telling (ownership) & Respons & Kurasi \\
Penyimpanan & & Motivasi & Jaringan antar-teks \\
Narasi (caption) & & & \\
\hline
\end{tabular}


Di luar motivasi eksternal yang diperoleh dari penyediaan teknologi (lihat Tabel 5), motivasi internal juga mereka bangun dari tujuan yang dianggap penting (ingin sehat, ingin menjadi pribadi yang lebih baik, ingin menguasai kecakapan baru) ataupun pengalaman pribadi yang dianggap berkesan (kenangan akan sosok nenek yang suka berkebun). Berbeda dengan motivasi pertama yang bersifat gratifikasi (sesuai premis U\&G), motivasi kedua hanya dapat diungkap dalam SLT. Lebih lanjut, informan menunjukkan bahwa pilihan tindakan bermakna lahir melalui refleksi diri, yang melahirkan kesadaran atas nilai transendental (lihat Tabel 4), maupun kesadaran bahwa aktivisme yang dilakukan memberi manfaat yang melampaui diri pribadi (lihat Kutipan Wawancara dengan Dedet). Dalam SL, motivasi ini mendukung proses regulasi diri dalam pembelajaran sosial lebih lanjut.

Dalam SL termediasi, tagar membantu pembentukan komunitas daring (Keir et al., 2021) dan memungkinkan lahirnya peta gagasan (Bonilla \& Rosa, 2015; Yang, 2016) karena terbentuknya jaringan tekstual dari penggunaan beberapa tagar secara bersamaan (lihat Tabel 1). Akibatnya, terbentuk jaringan antar-teks yang menguat ke dalam (sentripetal) dan ke luar (sentrifugal) secara bersamaan. Jaringan antar-teks yang menguat ke dalam ditandai dengan sifatnya yang lokal, sementara yang menguat ke luar ditandai dengan sifatnya yang global. Dari sisi pembelajaran sosial maupun gerakan kolektif, hal ini sangat strategis dan menguntungkan.

Di Bandung, misalnya, \#zerowaste dan \#plasticfree sering disandingkan bersama slogan dan avatar \#KangPisman, yang diciptakan pemerintah kota untuk mempromosikan gerakan lingkungan kota (urban environmental movement). Terdiri dari dua kata, yaitu "Kang" (sebutan lokal untuk kakak laki-laki) dan "Pisman" (singkatan kata dari "kurangi, pisahkan, manfaatkan"), pemerintah kota mengajak warganya mengurangi, memilah, dan mendaur ulang sampah. Tidak hanya ikon kebersihan, Kang Pisman juga melayani pesan pembangunan komunitas \#NyaahKaBandung. Pengertian "nyaah $k a$ Bandung" sendiri diambil dari ungkapan lokal yang mengandung makna kebanggaan dan keterikatan seseorang pada ruang hidup (belonging). Wawancara dengan Dedet (usia 34 tahun) mengonfirmasi hal ini. Saat ditanya tentang antusiasme warga kampung tempat tinggalnya dengan kegiatan \#KangPisman, ia menjawab:

"Antusias sekali. Awalnya, waktu $\mathrm{Bu}$ Tini (fasilitator komunitas) datang dan mengajak ibu-ibu untuk ikut pelatihan daur ulang sampah plastik, saya ikut-ikutan karena, saya kan pendatang, jadi saya ingin berbaur. Tapi sekarang, [setelah banyak perubahan terjadi di sini,] saya sudah jadi fasilitator komunitas untuk [program] Kang Pisman. Kami jadi percaya diri karena [kami merasa bahwa] tugas ini penting dan bermanfaat. Bulan depan saya akan menemani Bu Tini ke Bali untuk Jambore Bebas Sampah. Kami akan bertemu dengan orang-orang dari seluruh Indonesia yang bergerak di isu sampah. Ini akan jadi pengalaman pertama saya"

(Kutipan wawancara Dedet)

Sumber: penelitian lapangan, Januari 2020.

Saat wawancara dilakukan, kampung tempatnya tinggal merupakan salah satu dari tujuh kampung yang ditetapkan DKLH Kota Bandung sebagai 
proyek percontohan pembangunan kampung. Dengan aktif berpartisipasi dan menjadi fasilitator komunitas untuk program Kang Pisman, ia merasa menjadi bagian dari pembangunan kota dan komunitas di Bandung. Kampanye \#zerowaste dan \#plasticfree di Bandung yang terikat dengan Program Kang Pisman dan \#NyaahKaBandung, dengan demikian, berhasil mengembangkan sentimen positif berupa keterikatan dengan tempat tinggal (dwelling) di antara penduduknya serta rasa kepemilikan dan kebanggaan terhadap kota Bandung. Tagar yang sama juga menyatukan kerja berbagai aktor masyarakat sipil yang bekerja sama dengan pemerintah.

Selain terikat dengan gerakan lokal, \#zerowaste dan \#plasticfree juga terikat dengan gerakan global, seperti \#worldplasticfree (kampanye pengurangan sampah plastik), \#ecobrick (kampanye manajemen sampah plastik), dan \#ecoenzyme (kampanye pemanfaatan limbah organik dengan semangat citizen science yang berorientasi hulu ke hilir). Bertindak sebagai jaringan wacana, tagar menjadi penanda komunitas praksis sebagai sarana belajar dan partisipasi publik.

\section{KESIMPULAN}

Kajian ini berusaha mengisi kekosongan diskusi mengenai partisipasi warga negara dalam bingkai sustainabilitas. Penerapan konsep penyediaan dalam analisis menunjukkan keunggulan SLT dibandingkan U\&G dalam menjelaskan pengadopsian media tertentu.
Penyediaan teknologi yang diwakili Model MAIN mampu menjelaskan bagaimana aspek Modality, Navigability, Agency, dan Interactivity telah memfasilitasi proses melihat, menelusuri, menyimpan, hingga berinteraksi meluaskan jaringan dan menghimpun motivasi. Namun, penekanan Model MAIN pada aspek teknologi mereduksi faktor sosiokultural dalam SLT hanya sejak seseorang mulai berinteraksi dengan teknologi. Model MAIN, misalnya, tidak bisa menjelaskan bagaimana motivasi intrinsik yang bersumber dari pengalaman personal di masa lalu mendorong keterlibatan seseorang dalam SL. Model MAIN juga tidak bisa melihat nilai tindakan bermakna yang melampaui diri sendiri. Dengan mengembalikan gagasan penyediaan dalam SLT yang mengandung aspek manusia pembelajar dan konteks pembelajarannya, maka dinamika yang lahir dari hubungan ko-konstitutif ini dapat diakomodasi.

Penggunaan etnografi daring yang kerap menuai kritik akibat kurangnya sensibilitas etnografi diatasi dengan meleburkan batas luring/daring. Upaya mendekatkan diri dengan pengalaman informan dan merepresentasikan diri di komunitas amatan membantu menangkap pengalaman pembelajaran sosial di antara informan dalam aktivisme media sosial yang dijalaninya. Para perempuan yang menjadi subyek penelitian ini merespons permasalahan lingkungan global yang telah mengaburkan kedaulatan negara atas warganya dengan mengandalkan SL yang mendukung gagasan sustainabilitas. 


\section{DAFTAR PUSTAKA}

Bandura, A. (2001). Social cognitive theory of mass communication. Media Psychology, 3(3), 265-299. https://doi.org/10.1207/S1532785X MEPo303_03

Blewitt, J. (2006). The ecology of learning: Sustainability, lifelong learning, and everyday life. Earthscan.

Blumler, J. G., \& Katz, E. (1974). The uses of mass communication: Current perspectives on gratification research. Sage.

Bluteau, J. M. (2021). Legitimising digital anthropology through immersive cohabitation: Becoming an observing participant in a blended digital landscape. Ethnography, 22(2), 267285.

https://doi.org/10.1177/14661381198 81165

Bonilla, Y., \& Rosa, J. (2015). \#Ferguson: Digital protest, hashtag ethnography, and the racial politics of social media in the United States. American Ethnologist, 42(1), 4-17. https://doi.org/10.1111/amet.12112

Brown, M., Ray, R., Summers, E., \& Fraistat, N. (2017). \#SayHerName: A case study of intersectional social media activism. Ethnic and Racial Studies, 4O(11), 1831-1846. https://doi.org/10.1080/01419870.2 017.1334934

Chon, M. G., \& Park, H. (2020). Social media activism in the digital age: Testing an integrative model of activism on contentious issues. Journalism and Mass Communication Quarterly, 97(1), 7297.

https://doi.org/10.1177/1077699019 835896
Chwialkowska, A. (2019) 'How sustainability influencers drive green lifestyle adoption on social media: The process of green lifest. Management of Sustainable Development, 11(1), $33-43$.

Deaton, S. (2015). Social learning theory in the age of social media. Journal of Educational Technology, 12(1), 1-6.

Enli, G., \& Simonsen, C. A. (2018). 'Social media logic' meets professional norms: Twitter hashtags usage by journalists and politicians. Information Communication and Society, 21(8), 1081-1096. https://doi.org/10.1080/1369118X.2 017.1301515

Foster, M. D., Hennessey, E., Blankenship, B. T., \& Stewart, A. (2019). Can "slacktivism" work? Perceived power differences moderate the relationship between social media activism and collective action intentions through positive affect. Cyberpsychology, 13(4).

https://doi.org/10.5817/CP2019-4-6

Gibson, J. J. (1979). "The theory of affordances". In: The ecological approach to visual perception. Houghton Mifflin, 127-137.

Hammersley, M. (2006). Ethnography: Problems and prospects. Ethnography and Education, 1(1), 314.

Hootsuite We Are Social. (2021). Digital 2021.

http://www.wearesocial.com/digital2021

Jones, J. W. (1989). Personality and epistemology: Cognitive social learning theory as a philosophy of science. Zygon ${ }^{\circledR}$, 24(1), 23-38. https://doi.org/10.1111/j.14679744.1989.tboo974.x 
Keir, A., Bamat, N., Hennebry, B., King, B., Patel, R., Wright, C., Scrivens, A., ElKhateeb, O., Mitra, S., \& Roland, D. (2021). Building a community of practice through social media using the hashtag \#neoEBM. PLoS ONE, $16(5$ May 2021), 4-11. https://doi.org/10.1371/journal.pone .0252472

Liberatore, A., Bowkett, E., MacLeod, C. J., Spurr, E., \& Longnecker, N. (2018). Social media as a platform for a citizen science community of practice. Citizen Science: Theory and Practice, 3(1), https://doi.org/10.5334/cstp.108

Lim, M. (2012). Clicks, cabs, and coffee houses: Social media and oppositional movements in Egypt, 2004-2011. Journal of Communication, 62(2), 231-248.

https://doi.org/10.1111/j.14602466.2012.01628.x

Lim, M. (2013). Many clicks but little sticks: Social media activism in Indonesia. Journal of Contemporary Asia, 43(4), 636-657. https://doi.org/10.1080/00472336.2 013.769386

Markham, A. N. (2017). Ethnography in the digital era: From fields to flow, descriptions to interventions. In S. Denzin, Norman K. and Lincoln, Yvonna (Ed.), The Sage Handbook of Qualitative Research, 5th Edition (pp. 650-668). Sage.

McGregor, S. L. T. (2009). Reorienting consumer education using social learning theory: Sustainable development via authentic consumer pedagogy. International Journal of Consumer Studies, 33(3), 258-266. https://doi.org/10.1111/j.14706431.2009.00766.x
Micheletti, M. (2004). Discursive political consumerism and political participation. Ecpr.Eu. https://ecpr.eu/Filestore/PaperProp osal/faea2793-53be-4573-9b88778a5eeda26b.pdf

Moser, A., \& Korstjens, I. (2018). Series: Practical guidance to qualitative research. Part 3: Sampling, data collection and analysis. European Journal of General Practice, 24(1), 918.

https://doi.org/10.1080/13814788.2 017.1375091

Pyrko, I., Dörfler, V., \& Eden, C. (2017). Thinking together: What makes communities of practice work? Human Relations, 70(4), 389-409. https://doi.org/10.1177/0018726716 661040

Pyysiäinen, J. (2021). Sociocultural affordances and enactment of agency: A transactional view. Theory and Psychology.

https://doi.org/10.1177/0959354321 989431

Rathnayake, C., \& Winter, J. S. (2018). Carrying forward the uses and grats 2.0 agenda: An affordance-driven measure of social media uses and gratifications. Journal of Broadcasting and Electronic Media, 62(3), 371-389. https://doi.org/10.1080/08838151.2018. 1451861

Rheingold, H. (2000). The virtual community: Homesteading on the electronic frontiers (2nd Editio). MIT Press.

Ruggiero, T. E. (2018). Uses and gratifications theory in the 21st century. Refining Milestone Mass Communications Theories for the 21st Century, November, 36-70. https://doi.org/10.4324/9781315679 402-4 
Samudra, J. K. (2008). Memory in our body: Thick participation and the translation of kinesthetic experience. American Ethnologist, 35(4), 665681. https://doi.org/10.1111/j.15481425.2008.00104.x

Sorrell, J. M., \& Redmond, G. M. (1995). Interviews in qualitative nursing research: Differing approaches for ethnographic and phenomenological studies. Journal of Advanced Nursing, 21(6), 1117-1122. https://doi.org/10.1046/j.13652648.1995.21061117.x

Sundar, S. S. (2008). The MAIN model: A heuristic approach to understanding technology effects on credibility. In A. J. Metzger, Miriam J. dan Flanagin (Ed.), Digital Media, Youth, and Credibility (pp. 72-100). MIT Press. https://doi.org/10.1162/dmal.97802 62562324. 073

Sundar, S. S., \& Limperos, A. M. (2013). Uses and grats 2.0: New gratifications for new media. Journal of Broadcasting and Electronic Media, $57(4)$, 504-525. https://doi.org/10.1080/08838151.2 013.845827 vom Lehn, D., Hitzler, R., Honer, A., \& Hitzler, R. (2015). Life-worldanalytical ethnography: A phenomenology-based research approach. Journal of Contemporary Ethnography, 44(5), 544-562. https://doi.org/10.1177/08912416155 88589

Winter, R., \& Lavis, A. (2020). Looking, but not listening? theorizing the practice and ethics of online ethnography. Journal of Empirical Research on Human Research Ethics, 15(1-2), 5562.

https://doi.org/10.1177/15562646198 57529

Yang, G. (2016). Narrative agency in hashtag activism: The case of \#blacklivesmatter. Media and Communication, 4(4), 13-17. https://doi.org/10.17645/mac.v4i4.6 92 